\title{
TFAP2B wt Allele
}

National Cancer Institute

\section{Source}

National Cancer Institute. TFAP2B wt Allele. NCI Thesaurus. Code C52214.

Human TFAP2B wild-type allele is located within 6p21-p12 and is approximately $25 \mathrm{~kb}$ in length. This allele, which encodes transcription factor AP-2-beta protein, is involved in gene expression modulation during ectodermal differentiation. Missense mutations of the wild-type allele can lead to autosomal dominant Char syndrome. 